\title{
PENINGKATAN PERAN SERTA IBU- IBU DALAM RUMAH TANGGA MELALUI PELATIHAN PENDIDIKAN KARAKTER DAN KETERAMPILAN MEMBUAT MAKANAN JAJANAN BERBASIS BAHAN LOKAL
}

Jurnal Pendidikan Luar Sekolah

http://kolokium.ppj.unp.ac.id/ Jurusan Pendidikan Luar Sekolah Fakultas Ilmu Pendidikan Universitas Negeri Padang

Sumatera Barat, Indonesia

Volume 6, Nomor 2, Oktober 2018 DOI: $10.5281 /$ zenodo. 1471720

\author{
Setiawati,2, Syur'aini ${ }^{1}$ \\ 1Jurusan Pendidikan Luar Sekolah Fakultas Ilmu Pendidikan Universitas Negeri Padang \\ 2Email: setiawatipls@fip.unp.ac.id
}

\begin{abstract}
Women's participation in this case is housewives in supporting the family economy and children's education is currently very much needed. This is due to the increasing demands and needs of life today. In addition, if observed today, there has been a decline in the moral behavior of children and adolescents today, requiring serious handling by the family. The same thing was felt by the people of Lubuk Jantan, Lintau Buo Subdistrict, this problem was allegedly caused by the low understanding and skills of mothers about the character education and productive economic stability they had. This community service activity aims to enable housewives to (1) have skills in making cheap, lively, quality (3M) snacks based on local ingredients. (2) For young mothers to have motivation in enterpreneurship. (3) For young mothers to have the ability to market the results of their businesses. (4) For housewives to be able to shape their children's character towards a better direction. The target of this service is housewives in the Lubuk Jantan region, totaling 20 people. The results obtained from this service are, as a whole, the housewives who have been programmed already have some skills in making cheap, lively, quality snacks from local ingredients such as: from sea fish, from cassava, from white rice and glutinous rice, from flour and various kinds of pudding. In general, mothers who take part in the training have been able to instill the value of character values for children, because along with skills training, they are also given knowledge about planting character values in the family.
\end{abstract}

Keywords: Training to Make Snacks, Housewives

\section{PENDAHULUAN}

Keluarga merupakan lingkungan terkecil tempat berlangsungnya proses interaksi sosial (Wahy, 2012). Di mana setiap anggota keluarga mempunyai peran sosial masing-masing sesuai usia dan tingkat perkembangaan, yang dapat menimbulkan suatu efek bagi anggota keluarga yang lain di dalamnya, sehingga hal itu tentu akan dapat memengaruhi perkembangan sosial bagi anak, di usia remaja di dalam atau di luar keluarga itu sendiri.

Suatu hal yang tidak dapat dipungkiri adalah perkembangan teknologi informasi yang semakin canggih, mengakibatkan hampir dari semua pelosok dunia dapat diketahui, dan ketergantungan (interdepensi) antar bangsa semakin besar (Madjid, 2000). Perkembangan 
tersebut termasuk di dalamnya perkembangan ilmu pengetahuan, di samping mendatangkan kebahagiaan, juga menimbulkan masalah etis dan kebijakan baru bagi umat manusia. Efek samping itu ternyata berdampak sosiologis, psikologis, bahkan teologis, dan bahkan perubahan yang terjadi tersebut memengaruhi nilai-nilai yang selama ini dianut oleh masyarakat, sehingga terjadilah krisis nilai. Nilai-nilai kemasyarakatan yang selama ini dianggap dapat dijadikan sebagai sarana penentu dalam berbagai aktifitas, menjadi kehilangan fungsinya. Selain itu keberadaan ibu-ibu rumah tangga dalam menopang ekonomi keluarga dalam era sekarang amat sangat dibutuhkan, mengingat meningkatnya kebutuhan hidup dan biaya pengeluaran dan pendidikan anak-anak dewasa ini.

Untuk menyikapi fenomena global ini, maka penanaman nilai-nilai karakter kedalam diri anak secara dini sangat dibutuhkan. Pranata keluarga merupakan titik awal keberangkatan sekaligus sebagai modal awal perjalanan hidup anak. Selain itu keluarga juga diharapkan mampu memenuhi kehidupan finansial keluaga, karena kemiskinan itu akan mengakibatkan kemelaratan dan kemelaratan akan mengundang kekufuran.

Dari uraian di atas dapat ditarik suatu kesimpulan, bahwa disatu pihak orang tua sangat diharapkan untuk dapat memberikan pendidikan dan kehidupan yang layak terhadap anakanaknya, sementara di lain pihak, keterbatasan-keterbatasan yang terdapat pada keluarga menyebabkan mereka tidak dapat mewujudkannya.

Universitas Negeri Padang, melalui Tri Dharma Perguruan Tinggi Dharma ke 3, yaitu program pengabdian kepada masyarakatnya memiliki andil yang besar terhadap penanganan kemiskinan yang ada di Kota Padang. Hal ini disebabkan karena perguruan tinggi sangat kaya dengan para ilmuan yang sebenarnya sangat dibutuhkan dalam penanganan kemiskinan tersebut. Salah satunya adalah melalui kegiatan pemberian keterampilan kepada masyarakat. Dengan kondisi yang ada pada Universitas Negeri Padang, seyogyanya dapat memberi warna terhadap perkembangan dan kemajuan kelurahan dan sekaligus juga dapat membantu mengatasi masalah kemiskinan tersebut.

\section{PELAKSANAAN KEGIATAN}

Dalam melaksanakan kegiatan ini tim pengabdian bermitra dengan Wali Nagari Lubuk Jantan dan tokoh-tokoh masyarakat setempat. Sebagai mitra kami bekerja sama mulai dari analisis situasi, merencanakan kegiatan sampai pelaksanaan pengabdian dan penilaian kegiatan pengabdian ini.

Berdasarkan analisis kebutuhan yang dilakukan pada masyarakat Kenegarian Lubuk Jantan, tercatat dan terseleksi sebanyak 20 orang ibu-ibu rumah tangga, ternyata mereka berminat untuk meningkatkan keterampilannya di bidang makanan jajanan. Selanjutnya dalam membina dan membentuk karakter anak, kegiatannya diintegrasikan dengan kegiatan keterampilan yang diminati mereka.

Berdasarkan permasalahan yang dialami oleh keluarga yang bertempat tinggal di Kenagarian Lubuk Jantan, Kecamatan Lintau Buo, Kabupaten Tanah Datar dapat disimpulkan menjadi dua hal, yaitu masalah kemiskinan keluarga dan masalah karakter anak-anak yang kurang baik, maka target luaran yang akan dicapai pada kegiatan pelatihan ini adalah sebagai berikut: (1) Ibu-ibu rumah tangga terampil dalam membuat berbagai makanan jajanan yang murah, meriah dan bermutu (3M) berbasis bahan-bahan lokal; (2) Ibu-ibu rumah tangga memiliki motivasi berusaha dan dapat membuka usaha secara mandiri atau berkelompok; (3) 
Peningkatan Peran Serta Ibu-Ibu dalam Rumah Tangga...

Ibu-ibu rumah tangga memiliki kiat-kiat untuk berusaha dan untuk memasarkan makanan jajanan yang mereka produksi.

Kegiatan ini dilaksanakan dalam dua bentuk, yakni penyuluhan dan pelatihan. Penyuluhan adalah untuk membekali ibu-ibu rumah tangga agar meraka memiliki kiat-kiat untuk menumbuhkan motif berusaha yang sesuai dengan keterampilan yang dibutuhkan, dan tentang pemahaman dan aplikasi nilai-nilai karakter bangsa yang sangat dibutuhkan dalam membentuk perilaku yang baik dan sekaligus menjadi faktor pendukung dalam pengembangan kemandirian di dalam masyarakat yang dilanda globalisasi. Untuk itu digunakan metode ceramah, tanya jawab dan diskusi. Sedangkan pelatihan digunakan untuk menyampaikan materi keterampilan tentang memasak makanan jajanan berbasis bahan lokal, digunakan metode eksperimen yaitu masing-masing peserta pelatihan mencobakan sampai mereka terampil.

\section{HASIL YANG DICAPAI}

Keberhasilan kegiatan ini dapat dilihat dari segi proses pelaksanaan, peningkatan pengetahuan dan terjadinya peruhan keterampilan dan sikap. Dari segi proses, terlihat kehadiran peserta mulai dari pembukaan sampai pada penutupan adalah 100\%. Dari hasil, dapat diukur dengan kemampuan para ibu-ibu tersebut dalam membuat makanan jajanan berbasis bahan lokal. Hal ini dapat dilihat dari telah dapatnya mereka memasarkan hasil praktik dari berbagai jenis makanan jajanan tersebut. Di kalangan pelajar dan warung-warung di sekitar, dan bahkan mereka sudah menerima pesanan dari berbagai instansi. Selain itu melalui bimbingan dari Tim Pengabdian UNP, mereka telah membentuk kelompok belajar usaha yang diberi nama dengan "KBU Maju Bersama"

Yang diketuai oleh Yusnimar, salah seorang peserta, di mana mereka pilih secara musyawarah. Selain itu melalui tanya jawab peserta tersebut juga kelihatannya sudah memahami tentang nilai-nilai karakter dan cara-cara penanaman nilai-nilai karakter tersebut dalam keluarga.

\section{PEMBAHASAN}

\section{Pendekatan Program Berbasis Masyarakat}

Tidak dapat dipungkiri, keterlibatan masyarakat dalam kegiatan pengabdian kepada masyarakat ini amat dibutuhkan, karena kegiatan ini pada prinsipnya adalah untuk masyarakat, oleh masyarakat dan dari masyarakat. Prinsip utama yang dilakukan dalam kegiatan berbasis masyarakat ini adalah mengupayakan keterlibatan masyarakat dan tokoh-tokoh terkait dalam masyarakat, mulai dari analisis masalah, penetapan prioritas, pelaksanaan, evaluasi dan tindak lanjut dari program yang dilaksanakan. Hal ini diharapkan selain mereka ikut berpartisipasi terhadap program yang dilaksanakan, merasa memilki dan harapan terakhir bisa mengembangkan program tersebut di masa yang akan datang. Sehubungan dengan hal di atas, Sihombing (2002) menjelaskan bahwa prinsip utama dalam menjalankan program berbasis masyarakat adalah tercermin dalam akronim KAPASITAS (Kemitraan, Advokasi, Pemberdayaan, Analisis, Swadaya, Integrasi, Terfokus, Aksi nyata dan Sustainabilitas). 


\section{Orang Dewasa Sebagai Sibelajar}

Proses pendidikan berlangsung seumur hidup, mulai dari lahir sampai akhir kehidupan manusia. Pendidikan memiliki peranan penting bagi manusia untuk mendapatkan kehidupan yang lebih baik. Pendidikan itu tidak hanya diberikan kepada anak-anak dalam upaya menuju kedewasaannya serta pengembangan seluruh potensi yang mereka miliki, tetapi juga dibutuhkan oleh orang dewasa untuk mewujudkan eksistensi dirinya dalam menjalani kehidupan sehari-hari. Walaupun keduanya sama-sama belajar, namun belajar orang dewasa jauh berbeda dengan anak-anak belajar, baik dari aspek belajar, makna belajar, karakteristik dan model pembelajaran maupun cara belajar mereka (Asmin, 2011). Oleh karena itu belajar bagi orang dewasa memerlukan pendekatan yang berbeda pula. Menyamakan pendekatan untuk pendidikan anak-anak dengan orang dewasa dalam kegiatan pembelajaran, hal ini menyebabkan ketidakberhasilan belajar bagi orang dewasa bahkan merupakan hal yang menyakitkan bagi mereka.

Perbedaan antara anak-anak dan orang dewasa dalam pembelajaran antara lain bahwa orang dewasa memiliki pengalaman yang berbeda dengan anak-anak. Bagi anak-anak pengalaman adalah sesuatu yang terjadi padanya atau stimulus dari luar, sedangkan pengalaman bagi orang dewasa adalah sesuatu yang telah terintegrasi dalam dirinya. Selain itu orang dewasa memiliki konsep diri yang berbeda dengan anak-anak. Seorang anak yang sebenarnya adalah kertergantungan kepribadian kepada orang lain. Sementara orang dewasa sudah mampu berdiri sendiri dan mampu membuat keputusan sendiri (Rogers, 1994). Dalam kaitannya dengan kesiapan belajar, di antara orang dewasa juga jauh berbeda dengan anak-anak. Orang dewasa siap untuk belajar ketika apa yang dipelajari sesuai dengan kebutuhan mereka. Sementara kesiapan belajar bagi anak-anak telah dikondisikan oleh guru atau orang dewasa lainya (Raharjo \& Suminar, 2016). Menurut Solfema (2013) orang dewasa belajar berdasarkan kebutuhannya. Kebutuhan ini harus nyata serta harus sesuai dengan pengalaman peserta didik dewasa. Jika orang dewasa mendapat kesan bahwa pengalamannya tidak sedang dihargai ia merasa ditolak sebagai pribadi. Pembelajaran baru mengambil makna sebagai orang dewasa dapat mengaitkannya dengan pengalaman hidup mereka.

Pendidik dalam pembelajar untuk orang dewasa yang berpengalaman, mereka akan, membangun ke dalam desain pengalaman belajar mereka penyediaan bagi peserta didik untuk merencanakan dan berlatih bagaimana mereka akan menerapkan pembelajaran mereka dalam kehidupan sehari-hari atau tugas-tugas mereka dan menggabungkan pelatihan dengan transfer dan aplikasi (Lunandi, 1982).

Dengan mempedomani pendapat ahli di atas, tim pengabdian berupaya memberikan pelatihan yang betul-betul dibutuhkan masyarakat, sehingga terlihat rasa senang dan semangat yang tinggi dari mereka dalam mengikuti pelatihan, baik dalam pengadaan peratan, bahan maupun dalam pembelajaran. Selain memperhatikan kebutuhan belajar, dalam pembelajaran masyarakat, para perancang kegiatan pengabdian hendaknya perlu melibatkan semua sumber belajar dan sumber lembaga yang terkait dengan program pembelajaran yang dilakukan. Hal ini selain dapat memperlancar kegiatan, dan sekaligus dapat menumbuhkan kepada pihak lembaga rasa memilki akan program tersebut, dan diharapkan kegiatan ini bisa berlangsung dan berkesinambungan. seperti apa yang dijelaskan oleh (Setiawati, 2013). Melibatkan perangkat kelurahan dan lembaga PKBM dalam program pengabdian ini sudah dilakukan oleh tim pengabdian UNP. Sehubungan dengan hal di atas, kami bermitra dengan pemerintah setempat yaitu wali nagari dan perangkat korong, Kelihatannya walaupun kegiatan pengabdian 
Peningkatan Peran Serta Ibu-Ibu dalam Rumah Tangga...

sudah berhasil, namun pelaksanaan kegiatan menerima pesanan makanan ini tetap berjalan sampai sekarang.

\section{KESIMPULAN}

Berdasarkan pengalaman selama melaksanakan pengabdian kepada masyarakat dan perolehan hasil yang diperolah maka dapat ditarik kesimpulan sebagai berikut:

1) Perlu dilakukan identifikasi kebutuhan dan sumber belajar terhadap sasaran pada setiap pelaksanaan pengabdian kepada masyarakat sebab dengan memberikan pengetahuan dan keterampilan yang sesuai dengan kebutuhan mereka, kelihatannya dapat memecahkan masalah yang mereka hadapi.

2) Melibatkan lembaga yang terkait dengan program yang dilaksanakan, sangat perlu dilakukan, karena berdasarkan pengalaman yang dirasakan, akan sangat membantu kelancaran pelasanaan dan sekaligus dapat menunjang keberlanjutan program yang kita laksanakan.

\section{DAFTAR RUJUKAN}

Asmin. (2011). Konsep dan Metode Pembelajaran untuk Orang Dewasa (Andragogi). https://doi.org/10.1016/j.jog.2012.02.009

Lunandi, A. (1982). Pendidikan Orang Dewasa, Sebuab Uraian Praktis Untuk Pembimbing, Penatar, Pelatih dan Penyulub Lapangan. Jakarta: Gramedia.

Madjid, N. (2000). Islam Doktrin dan Peradaban; Sebuab Telaah Kritis tentang Masalab Keimanan, Kemanusiaan dan Kemodernan (Cetakan Ke). Jakarta: Paramadina.

Raharjo, T. J., \& Suminar, T. (2016). Penerapan Pedagogi dan Andragogi Pada Pembelajaran Pendidikan Kesetaraan Kelompok Belajar Paket A, B, dan C di Kota Semarang. Edukasi, 1(1). Retrieved from https://journal.unnes.ac.id/nju/index.php/edukasi/article/download/954/891

Rogers, A. (1994). Teaching Adults. Milton Keynes. Philadelphia: Open University Press.

Setiawati. (2013). Analisisi Kebutuhan dan Sumber Belajar Belajar Masyarakat. Padang.

Sihombing, U. (2002). Menuju Pendidikan Bermakna Melalui Pendidikan Berbasis Masyarakat. Jakarta: CV Multiguna.

Solfema. (2013). Andragogi Konsep dan Penerapannya. Malang: Wineka Cipta.

Wahy, H. (2012). Keluarga Sebagai Basis Pendidikan Pertama Dan Utama. Jurnal Ilmiah DID AKTIKA Februari, XII(2), 245-258. 